\title{
Evaluation of Pole Type French Bean (Phaseolus vulgaris L.) Genotypes under Raichur Region
}

\author{
Praveenkumar Angadi* and M.G. Patil \\ Department of Horticulture, College of Agriculture, Raichur-584410, Karnataka, India \\ *Corresponding author
}

A B S T R A C T

In the present investigation diverse genotypes of French bean were evaluated to identify higher yielding genotypes with important yield component traits. Seven genotypes of pole

Keywords

French bean, EC530833, IC-319827, Maximum yield,

Genotypes, Phaseolus vulgaris $\mathrm{L}$.

Article Info

Accepted:

20 September 2017

Available Online:

10 November 2017 type French bean viz., EC-530833, IC-320968, EC-500638, IC-319827, EC-540796, IC319423 and EC-530838were assessed for performance at Main Agriculture Research Station, Raichur. Highly significant differences were observed in the genotypes for all the characters under study. An overall perusal on the performance of genotypes revealed that EC-530833 registered maximum yield hectare ${ }^{-1}$ (17.02 t) followed by IC-319827 (16.62t) and IC-319423 (16.32t) whereas; EC-530838 recorded minimum pod yield hectare ${ }^{-1}$ (15.13t). Plant height, number of branches plant ${ }^{-1}$, stem thickness, leaf area, LAI, number of pods plant ${ }^{-1}$, ovule number pod ${ }^{-1}$, weight of 10 pods, number of seeds pod $^{-1}$ and pod yield plant ${ }^{-1}$ showed significant difference among the genotypes. Among seven genotypes EC-530833 registered the highest in all the above characters $(152.00 \mathrm{~cm}, 50.47,9.49 \mathrm{~mm}$, $98.22 \mathrm{~cm}^{2}, 5.46,80.29,7.40,37.80 \mathrm{~g}, 7.03$ and $255.33 \mathrm{~g}$ ) also showed less number of leaf miner maggot's leaf ${ }^{-1}$. It can be concluded that the difference in yield may be attributed mainly to the difference in their pod length, number of pods plant $^{-1}$, pod weight, leaf area, number of seeds pod $^{-1}$, number of branches plant ${ }^{-1}$.

\section{Introduction}

It is an essential to evaluate high yielding genotypes since a superior genotype may exhibit its potentiality when grown under a set of agro climatic condition. Yield being a complex trait, is collectively influenced by various yield attributes, which are polygenically inherited and influenced by environmental variations. The effective selection for improvement of these traits is determined by magnitude and nature of interaction between genotypic and phenotypic variability. French bean, Phaseolus vulgaris L. $(2 \mathrm{n}=2 \mathrm{x}=22)$ also known as snap bean, kidney bean, garden bean or string bean, is one of the most important leguminous vegetables grown for its tender fleshy green pods, shelled green seeds and also dry beans. It has anti-diabetic property and is good for natural cure of bladder burns and cardiac problems, diarrhoea, sciatica and tenesmus. It is a nutritive vegetable, rich in protein $(1.7 \mathrm{~g})$, calcium (132 mg), thiamin $(0.08 \mathrm{mg})$ and vitamin C (24 mg $100 \mathrm{~g}^{-1}$ of edible pods). French bean originated from Central America and Peruvian Andes in South America (Vavilov, 1950). It is grown in the world in an area of $0.83 \mathrm{~m}$ ha with annual production of $5.64 \mathrm{~m} \mathrm{t}$ with productivity of $6.76 \mathrm{t} \mathrm{ha}^{-1}$. In 
India, it is mainly grown in Himachal Pradesh Punjab, Haryana, Uttar Pradesh, Bihar, Gujarat, Madhya Pradesh, Maharashtra, Karnataka, Andhra Pradesh and Tamil Nadu. Annually, French bean is grown in an area of $0.15 \mathrm{~m}$ ha with annual production of $0.42 \mathrm{mt}$ and productivity of $2.8 \mathrm{t} \mathrm{ha}^{-1}$ (FAO STAT, 2002). Selection for architectural traits along with some yield components is expected to produce bean plant ideotypes possessing higher yield potential through enhanced adapting to specific cropping system (Durate and Adams, 1972). In the present investigation diverse genotypes of French bean were evaluated to identify higher yielding genotypes with important yield component traits.

\section{Materials and Methods}

The field experiment was conducted on sandy loam soil in the new orchard of Main Agriculture Research Station (MARS), Raichur, which is situated in the north eastern dry zone of Karnataka; the location corresponds to at $16^{\circ} 12^{\prime} \mathrm{N}$ latitude and $77^{\circ}$ $20^{\prime}$ E longitude with an altitude of $389 \mathrm{~m}$ above the mean sea level.

The daily climatological data during the study period were obtained from the meteorological observatory at MARS, Raichur. The investigation was carried out during Kharif season of 2010. It consists of seven genotypes collected from different sources. The experiment was laid out by adopting Randomised Block Design with three replications.

Thirty plants per genotype per replication were maintained. The experiment was conducted as per the package of practice of UAS, Dharwad. The observations were recorded from five randomly selected plants from each genotype in each replication for days to $50 \%$ flowering, plant height, number of branches plant ${ }^{-1}$, stem thickness, leaf area, leaf area index, chlorophyll content, number of pods plant ${ }^{-1}$, ovule number pod $^{-1}$, pod length, pod width, weight of 10 pods, number of seeds pod ${ }^{-1}$, tenderness of pods, pod yield plant $^{-1}$, pod yield hectare ${ }^{-1}$, shelf life and leaf minor maggots leaf $^{-1}$ using standard procedures. The collected pool data were subjected for statistical analysis.

\section{Results and Discussion}

The comparison of French bean genotypes indicated that they differed significantly in pod yield plant $^{-1}$, days to $50 \%$ flowering, plant height, number of branches plant ${ }^{-1}$, stem thickness, leaf area, leaf area index plant $^{-1}$, chlorophyll content, number of pods plant ${ }^{-1}$, Pod length, pod width and Pod yield hectare ${ }^{-1}$. The variation for pod yield plant ${ }^{-1}$ was noticed by many workers like Korla et al., (1998), Singh et al., (2000), Singh et al., (2007a), Atilla Duursum (2007). EC-530833 ranked first for pod yield $\left(255.33 \mathrm{~g} \mathrm{plant}^{-1}\right)$. IC319827 (249.33 g plant ${ }^{-1}$ ) and IC-319423 $\left(244.73 \mathrm{~g} \mathrm{plant}^{-1}\right)$ were next in the order. On the other hand EC-530838 (227.00g plant $\left.{ }^{-1}\right)$ was the least.

Thus, these four genotypes can safely replace the other genotypes whose yield is much lower (Table 1). IC-320968 recorded minimum number of days (40.33) for $50 \%$ flowering and closely followed by EC-500638 (41.00) and EC-530833 (43.67) whereas, IC319423 (48.33) had taken maximum number of days to $50 \%$ flowering. On an average, genotypes took 44.29 days for $50 \%$ flowering. The population mean for plant height was $133.52 \mathrm{~cm}$. Plant height was maximum in EC-530833 $(152.00 \mathrm{~cm})$ followed by IC-319827 $(150.33 \mathrm{~cm})$ and IC$320968(140.33 \mathrm{~cm})$. All these were statistically on par with each other whereas, EC-500638 (111.87) recorded least plant height. 


\section{Int.J.Curr.Microbiol.App.Sci (2017) 6(11): 2645-2650}

Table.1 Growth performance of pole type French bean genotypes

\begin{tabular}{|c|c|c|c|c|c|c|}
\hline \multirow[b]{2}{*}{ Genotypes } & \multicolumn{6}{|c|}{ Plant growth parameters } \\
\hline & $\begin{array}{l}\text { Plant height } \\
(\mathrm{cm})\end{array}$ & No. of branches & $\begin{array}{l}\text { Stem thickness } \\
(\mathrm{mm})\end{array}$ & $\begin{array}{l}\text { Leaf area } \\
\left(\mathrm{cm}^{2}\right)\end{array}$ & Leaf area index & $\begin{array}{l}\text { Chlorophyll estimation } \\
\left({\left.\mathrm{mg} 100 \mathrm{~g}^{-1}\right)}\right.\end{array}$ \\
\hline EC-530833 & 152.00 & 50.47 & 9.49 & 98.22 & 5.46 & 35.89 \\
\hline IC- 320968 & 140.33 & 29.40 & 7.49 & 66.82 & 3.71 & 31.44 \\
\hline EC-500638 & 111.87 & 26.60 & 8.27 & 75.21 & 4.18 & 28.57 \\
\hline IC- 319827 & 150.33 & 48.07 & 9.21 & 93.78 & 5.21 & 33.42 \\
\hline EC-540796 & 139.87 & 35.40 & 7.78 & 60.70 & 3.37 & 27.63 \\
\hline IC- 319423 & 118.47 & 33.20 & 8.40 & 95.46 & 5.30 & 26.95 \\
\hline EC-530838 & 121.80 & 27.80 & 9.33 & 76.93 & 4.27 & 32.71 \\
\hline Mean & 133.52 & 35.85 & 8.57 & 81.02 & 4.50 & 30.94 \\
\hline SEm \pm & 4.85 & 1.66 & 0.25 & 2.70 & 0.15 & 1.09 \\
\hline $\mathrm{CD}(p<0.05)$ & 14.94 & 5.10 & 0.77 & 8.32 & 0.46 & 3.35 \\
\hline
\end{tabular}

Table.2 Yield and yield attributing characters of pole type French bean genotypes

\begin{tabular}{|c|c|c|c|c|c|c|c|c|c|c|c|c|}
\hline \multirow[b]{2}{*}{ Genotypes } & \multicolumn{12}{|c|}{ Yield parameters } \\
\hline & $\begin{array}{c}\text { Days to } \\
50 \% \\
\text { flowering }\end{array}$ & $\begin{array}{c}\text { No. of } \\
\text { pods per } \\
\text { plant }\end{array}$ & $\begin{array}{c}\text { Tenderness } \\
\text { of pod } \\
\text { (tr value) }\end{array}$ & $\begin{array}{c}\text { Ovule } \\
\text { no. } \\
\text { Pod }^{-1}\end{array}$ & $\begin{array}{l}\text { Av. Wt. } \\
\text { Of } 10 \\
\text { pods }(g)\end{array}$ & $\begin{array}{l}\text { Pod } \\
\text { length } \\
(\mathrm{cm})\end{array}$ & $\begin{array}{l}\text { Pod } \\
\text { width } \\
(\mathrm{mm})\end{array}$ & $\begin{array}{l}\text { Av. No. } \\
\text { Seeds } \\
\text { pod }^{-1}\end{array}$ & $\begin{array}{l}\text { Pod } \\
\text { yield } \\
\text { plant }^{-1} \\
(\mathrm{~g})\end{array}$ & $\begin{array}{c}\text { Yield } \\
\text { hectare }^{-1} \\
\text { (t) }\end{array}$ & $\begin{array}{l}\text { Shelf } \\
\text { life } \\
\text { (days) }\end{array}$ & $\begin{array}{c}\text { No. of Leaf } \\
\text { miner maggots } \\
\text { leaf }^{-1}\end{array}$ \\
\hline EC-530833 & 43.67 & 80.29 & 40.33 & 7.40 & 37.80 & 11.17 & 11.14 & 7.03 & 255.33 & 17.02 & 5.00 & 5.96 \\
\hline IC- 320968 & 40.33 & 70.63 & 51.68 & 4.67 & 35.60 & 12.66 & 11.96 & 4.53 & 231.58 & 15.44 & 6.00 & 9.19 \\
\hline EC-500638 & 41.00 & 71.73 & 51.75 & 5.33 & 32.53 & 9.20 & 9.52 & 5.03 & 237.33 & 15.82 & 4.00 & 8.07 \\
\hline IC- 319827 & 45.00 & 77.43 & 39.83 & 6.87 & 35.53 & 11.07 & 10.14 & 6.37 & 249.33 & 16.62 & 5.00 & 9.22 \\
\hline EC-540796 & 45.33 & 63.70 & 51.42 & 6.67 & 35.40 & 10.63 & 9.90 & 6.53 & 228.67 & 15.24 & 4.00 & 11.15 \\
\hline IC- 319423 & 48.33 & 74.14 & 36.58 & 6.00 & 35.27 & 10.88 & 10.54 & 5.03 & 244.73 & 16.32 & 7.00 & 9.15 \\
\hline EC-530838 & 46.33 & 66.76 & 50.33 & 6.67 & 30.13 & 10.07 & 9.50 & 6.53 & 227.00 & 15.13 & 4.00 & 9.63 \\
\hline Mean & 44.29 & 72.10 & 45.99 & 6.23 & 34.61 & 10.81 & 10.39 & 5.87 & 239.14 & 15.94 & 5.00 & 8.91 \\
\hline SEm \pm & 1.02 & 2.45 & 1.52 & 0.23 & 1.11 & 0.34 & 0.31 & 0.24 & 4.94 & 0.33 & 0.32 & 0.42 \\
\hline $\mathrm{CD}(p<0.05)$ & 3.15 & 7.56 & 4.68 & 0.70 & 3.43 & 1.04 & 0.94 & 0.75 & 15.21 & 1.01 & 0.99 & 1.28 \\
\hline
\end{tabular}


Fig.1 Performance of seven pole type French bean genotypes with respect to yield ha ${ }^{-1}$

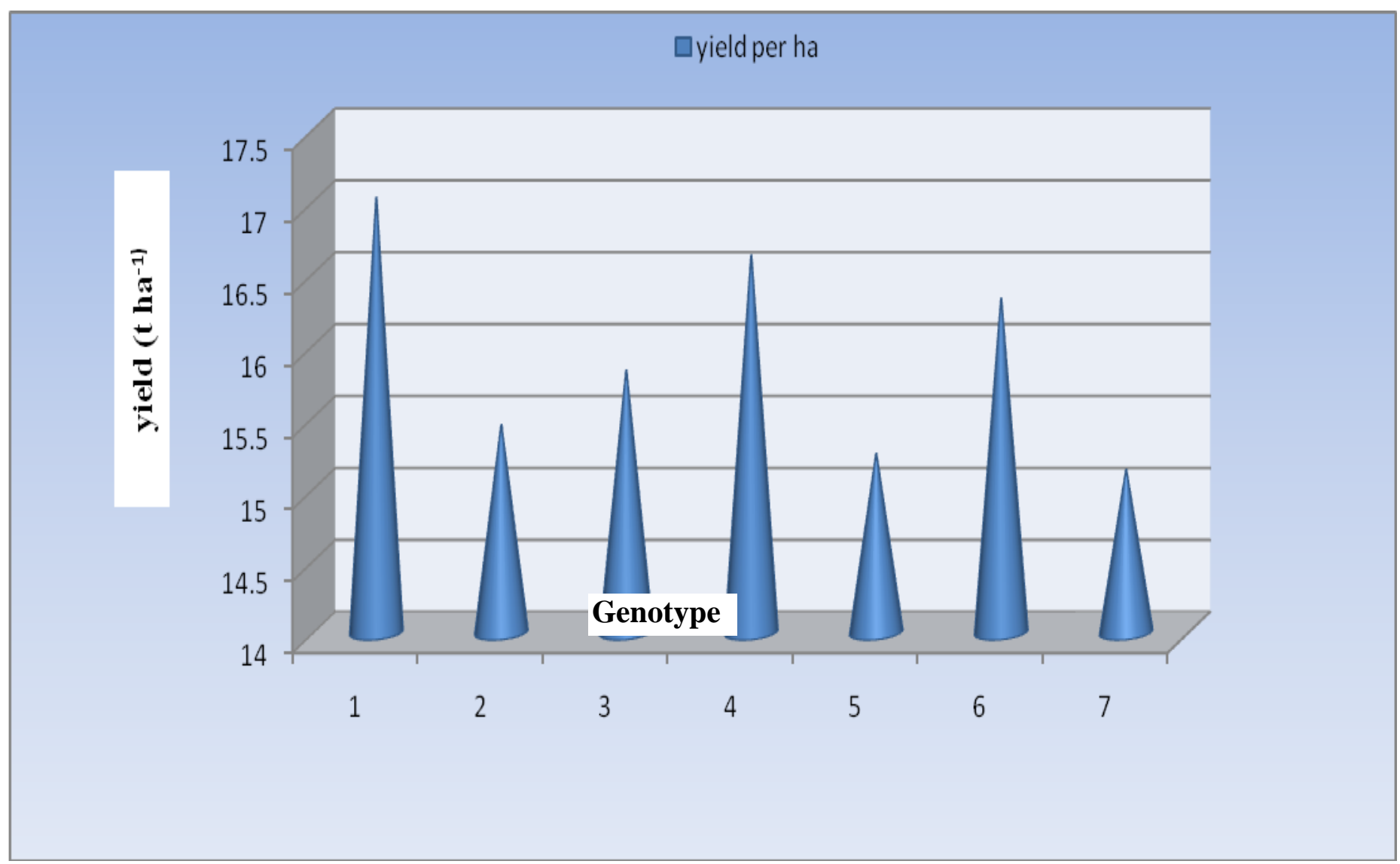

1. EC-530833

2. IC- 320968

3. EC-500638

4. IC- 319827

5. EC-540796

6. IC- 319423

7. EC-530838 
The population mean for number of branches plant $^{-1}$ was 35.85 and number of branches plant $^{-1}$ was maximum in EC-530833 (50.47) followed by EC-319827 (48.07) and EC540796 (35.40) whereas, EC-500638 (26.60) showed least number of branches plant ${ }^{-1}$. Stem thickness was significantly superior in EC-530833 (9.49); this is on par with EC530838 (9.33) and IC-319827 (9.21) whereas, least stem thickness recorded in IC-320968 (7.49). The population mean for leaf area was $81.02 \mathrm{~cm}^{2}$. The maximum leaf area plant ${ }^{-1}$ was in EC-530833 $\left(98.22 \mathrm{~cm}^{2}\right)$ followed by IC-319428 $\left(95.46 \mathrm{~cm}^{2}\right)$ and IC-319827 (93.78 $\mathrm{cm}^{2}$ ) whereas, least was recorded in EC$540796\left(60.70 \mathrm{~cm}^{2}\right)$. The leaf area index plant $^{-1}$ was maximum in IC-530833 (5.46) followed by IC-319423 (5.30) and IC-319827 (5.21) whereas, lesser leaf area index observed in EC-540796 (3.37). There was a significant difference between genotypes for chlorophyll content and it was maximum in EC-530833 (35.89) followed by IC-319827 (33.42) and EC -530838 (32.71) whereas, minimum chlorophyll content was recorded in IC-319473(26.95). For number of pods plant ${ }^{-1}$ EC-530833(80.29) recorded maximum followed by IC-319827(77.43) and IC319423(74.14) whereas, least number of pods plant $^{-1}$ was found in EC-540796 (63.70). The population mean for number of pods plant ${ }^{-1}$ was 72.10. Significant difference was obtained even for ovule number pod ${ }^{-1}$ among the genotypes. Maximum number of ovules $\operatorname{pod}^{-1}$ was found in EC-530833 (7.40) followed by IC-319827 (6.87) whereas, least was recorded in IC-320968(4.67). The population mean for pod length was 10.81 $\mathrm{cm}$. Pod length was maximum IC-320968 (12.66) followed by EC-530833 (11.17), IC319827 (11.07) whereas, least pod length recorded in EC-500638 (9.2). Pod width was recorded maximum in EC-320968 (11.96) followed by EC-530833 (11.14) and IC319423 (10.54) whereas, it was least observed in EC-530838 (9.50) and the population mean for weight of 10 pods was $34.61 \mathrm{~g}$. Maximum weight was recorded by EC-530833 (37.80) followed by IC-320968 (35.60) and IC319827 (35.53) whereas, it was least observed in EC-530838 (30.13). On an average number of seeds pod $^{-1}$ were 5.87. Number of seeds pod $^{-1}$ recorded maximum in EC-530833 (7.03) followed by EC-540796 (6.53) and EC530838 (6.53). All these genotypes were statistically on par with each other, whereas least number of seeds $\operatorname{pod}^{-1}$ was recorded in IC-320968 (4.53). IC-319423 recorded minimum tr value (36.58) followed by IC319827 (39.83) and EC-530833 (40.33). Whereas, EC-500638 (51.75) showed maximum tr value. Pod yield hectare ${ }^{-1}$ was recorded maximum in EC-530833 (17.02t) followed by IC-319827 and IC-319423 (16.62 $\mathrm{t} \& 16.32 \mathrm{t}$ respectively) whereas, it was least in EC-530838 (15.13 t). The population mean for total yield hectare ${ }^{-1}$ was $15.94 \mathrm{tha}^{-1}$. The maximum shelf life was recorded in IC319423 (7.00) followed by IC-320968 (6.00), EC-530833 and IC-319827 (5.00) whereas, minimum shelf life was observed in EC500638, EC-540796 and EC-530838 (4.00). There were minimum leaf miner maggots leaf $^{-1}$ in EC-530833(5.96) followed by EC500638 (8.07) and IC-319423 (9.15) whereas, maximum was observed in EC-540796 (11.15) (Table 2; Fig. 1).

From the present investigation it can be concluded that the difference in yield may be attributed mainly to the difference in their pod length, number of pods plant ${ }^{-1}$, pod weight, leaf area, number of seeds pod $^{-1}$, number of branches plant ${ }^{-1}$. In the study, number of branches plant ${ }^{-1}$, leaf area, number of pods plant $^{-1}$, pod length, pod width, weight of 10 pods, and number of seeds pod $^{-1}$ showed significant difference among the genotypes. Among several genotypes EC-530833 registered the highest in all the above characters. This might be one of the reasons for higher yield which is recorded in EC- 
530833. This is in conformity with the studies of Singh et al., (2000), Nimbalkar et al., (2002), Singh et al., (2007a) and Atilla, (2007).

\section{References}

Atilla, D., 2007. Variability, heritability and correlation in french bean (Phaseolus vulgaris L.) genotypes. World studies journal of Agriculture Sciences, 3(1): 12-16.

Durate, R.A., Adams, M.W., 1972. A path coefficient analysis in field bean (Phaseolus vulgaris L.). Crop Sciences, 12: 579-582.

FAO STAT., 2002. http:/www.fao.org.

Korla, B.N., Thakur, A.S., Joshi, A.K., 1998. Variability studies in beans (Phaseolus $\begin{array}{lll}\text { vulgaris } & \text { L.). Haryana Journal }\end{array}$
Horticulture Sciences, 27(1): 43-48.

Nimbalkar, C.A., Baviskar, A.P., Desai, U.T., 2002. Selection strategy for yield improvement in rajmash (Phaseolus vulgaris L.). Indian Journal of Genetics, 62(4): 349-351.

Singh, A.K., Singh, K.P., Singh, B.K., 2007. Evaluation and screening of french bean genotypes for high yields. Haryana Journal Horticulture Sciences, 36(3-4): 354-355.

Singh, B.K., Singh, B.P., Ram H.H., 2000. Variability and correlation studies in bush type french bean (Phaseolus vulgaris L.) in relation to green pod yield. Progressive Horticulture, 32(2): 176-182.

Vavilow, N.I., 1950. The origin, variation and breeding of cultivated plants. Chronicle Botany, 13: 1-364.

\section{How to cite this article:}

Praveenkumar Angadi and Patil, M.G. 2017. Evaluation of Pole Type French Bean (Phaseolus vulgaris L.) Genotypes under Raichur Region. Int.J.Curr.Microbiol.App.Sci. 6(11): 2645-2650. doi: https://doi.org/10.20546/ijcmas.2017.611.310 